$\begin{array}{ll}\text { Abstracta Iranica } & \begin{array}{l}\text { Abstracta Iranica } \\ \text { Revue bibliographique pour le domaine irano-aryen }\end{array} \\ & \text { Volume } \mathbf{3 1} \mid \mathbf{2 0 1 1} \\ & \text { Comptes rendus des publications de } \mathbf{2 0 0 8}\end{array}$

«Les infinitifs en persan ». Faits de Langue, 2008, p. 117-134.

Soha Safaï

\title{
OpenEdition
}

1 Journals

Édition électronique

URL : http://journals.openedition.org/abstractairanica/39120

DOI : 10.4000/abstractairanica.39120

ISSN : 1961-960X

Éditeur :

CNRS (UMR 7528 Mondes iraniens et indiens), Éditions de l'IFRI

Édition imprimée

Date de publication : 15 mai 2011

ISSN : 0240-8910

Référence électronique

Soha Safaï, « "Les infinitifs en persan ». Faits de Langue, 2008, p. 117-134. », Abstracta Iranica [En

ligne], Volume 31 | 2011, document 21, mis en ligne le 15 février 2012, consulté le 29 septembre 2020. URL : http://journals.openedition.org/abstractairanica/39120 ; DOI : https://doi.org/10.4000/ abstractairanica.39120

Ce document a été généré automatiquement le 29 septembre 2020.

Tous droits réservés 


\section{« Les infinitifs en persan ». Faits de Langue, 2008, p. 117-134.}

\section{Soha Safaï}

Les AA. examinent les propriétés morphologiques et syntaxiques des infinitifs en persan, afin de déterminer s'ils ont un emploi nominal ou verbal. A partir de l'étude de différents exemples d'infinitifs dans des situations très variées, ils établient qu'il existe deux emplois distincts pour l'infinitif, l'un nominal, l'autre verbal. Pour l'emploi verbal, il apparaît que l'infinitif n'a que des propriétés verbales; en revanche, dans le second cas, il présente des propriétés syntaxiques mixtes, à la fois nominales et verbales. Ce second cas est traité dans le cadre du modèle HPSG, la démonstration prenant en compte la totalité des cas possibles.

\section{INDEX}

Thèmes : 2.2. Langues vivantes et dialectes

\section{AUTEURS}

SOHA SAFAÏ

Paris 